Irena Górska*

Adam Mickiewicz University

\title{
LIBERATURE IN RELATION TO THE RECONFIGURATION OF AISTHESIS
}

\begin{abstract}
This article proposes to inspect the phenomenon of liberature from the perspective of the reconfiguration of aisthesis, as described by Wolfgang Welsch. In the German researcher's approach, this consists in questioning the primacy of vision in favour of other senses, and is, first of all, an effect of the dominance of the media. However, in a broader approach towards the reasons of transformations, aisthesis must be looked for in phenomena that are summarised in the formula of "new aesthetics", as proposed by Arnold Berleant. One of the significant features of this concept is the constant expansion of the area of art and the appearance of forms that stimulate the audience's experience, requiring the activation of new sensory receptors. Without a doubt, liberature is one of those forms of art that requires interactivity and a special involvement. Being a unique example of the co-existence of various types of messages (verbal, iconic and material), liberature requires a polysensory perception. This, in turn, can be a source of aesthetic satisfaction, but also a reason for an impoverishment of the aesthetic experience spanning between aisthesis and anaisthesis.
\end{abstract}

Key words: liberature, aisthesis, aesthetic experience, polysensory perception

Every culture and every age has its favorite model of perception and knowledge that it is inclined to prescribe for everybody and everything. The mark of our time is its revulsion against imposed patterns. (McLuhan 1964: 6).

Even the distinctions among the arts have broken down, and we are often unable to decide where a new development belongs - whether, for example, environments are sculpture or architecture; assemblages are paintings or sculptures; Happenings are theater, painting (as an outgrowth of action painting), or an entirely new art form synthesizing elements of theater, sculpture, dance, painting, and music (Berleant 2004: 57).

* Polish Philology Department, Adam Mickiewicz University, A. Fredry 10, 61-701 Poznan, e-mail: irenaszandor@poczta.onet.pl 
The doubts expressed by Arnold Berleant could, to some extent, also refer to the phenomenon of liberature. It is difficult to claim that liberature is simply literature, or even a fourth literary genre, as Zenon Fajfer postulated some time ago (Fajfer $2010 \mathrm{~A})^{1}$. Liberature should rather be seen as a peculiar kind of art, which combines the verbal, the iconic, and the material. Liberature remains a specific combination of mutually determining contents and material form of a work, and constitutes a "combination of textual semiosis with the semiosis of the material medium" (Kalaga 2010: 11). Moreover, according to a checklist by Katarzyna Bazarnik, a work of liberature uses typographical means of expression, spatial organization of the text, self-reflexivity or metatextuality, hybridity, interactivity, and ergodicity (Bazarnik 2010: 160-161). It is even possible to say that liberature spans between literature and visual arts. Moreover, in a sense it refers even to architecture, and, at that, in two dimensions: the space of text on a page, as it "plays" with its own "texture" (cf. Tekst-tura, 2005), and the space of the material medium itself, as it often does not resemble the traditionally binded book. It is also important that the function of external form is not merely practical or ornamental, but above all the external form becomes a carrier of meanings that are inseparably linked with the content. There is, consequently, no exaggeration in the statement that liberature is the most literal embodiment of Marhall McLuhan's famous dictum that the medium is the message. This peculiar entangling of form and content is very consequential. It makes it almost impossible to inscribe a work of liberature into another medium. According to Katarzyna Bazarnik, the characteristic features of a work of liberature, especially the material and iconic ones, disappear or are distorted in the process. This is why the concept of e-liberature seems to be a little misguided (Bazarnik 2010: 161-163 A).

A separate, and highly important question is posed by the fact that technology distorts the intensity of the direct, sensual contacts with any work of art. Materiality which, according to Bazarnik, is the genre-defining feature of liberature (Bazarnik 2010 B), disappears in e-space. At best, it can be replaced by its own image. Each materialization of a work in the media is more like an archivization, as Grzegorz Dziamski observes. An archivization points out to what a work could look like, but not to what it indeed is (Dziamski 2007: 207). In this context, Rüdiger Bubner's words seem to be particularly appropriate, when he claims that "sensual directness cannot be transmitted by technical means" (Bubner 2005: 71).

1 Unless otherwise indicated, all the quotations from non-English texts are translated by the author of the article. 
It is noteworthy that liberature has an undoubted advantage not only over traditionally published books, but also over electronic publications, which is because liberature, by demanding a peculiar kind of perception, introduces more qualities into the experience of reception. This is because the electronic book, according to Tomasz Goban-Klas, usually preserves the significant qualities of the original publication, and is consequently read in a linear manner, just like a traditionally published paper book. The important change is the lack of physical contact with the material substance of the book, which is replaced by the monitor of an electronic reader (Goban-Klas 2001: 124-125). The content, thus, has been transferred onto another medium, which obviously changes the reader's interaction with a work, and demands, as Małgorzata Sopyło observes, skills in the use of electronic devices (Sopyło 2008). It must be emphasized that the e-book demands, above all, reading, whereas liberature asks for other kinds of reader's activity.

It seems, thus, that the specific peculiarity of liberature as a form of art is the fact that, in the age of popularity of audiobooks and e-books, it demands a direct, physical contact with its own material substance. This is because liberature is a graphic display of the conviction that the work of art is, as Mieczysław Wallis wrote some years ago, "part of its own physical medium" (Wallis 2004: 67), or more aptly: "It is nothing but its own material substance" (Pareyson 2009: 59)2. Thus, both the artistic and the aesthetic dimensions of the work are determined by its materiality. A change of one medium/transmitter into another would actually disintegrate the essence of a work of liberature, by destroying its multidimensionality.

As a context for the argument presented above, there is another important reference to McLuhan: "The printed book had encouraged artists to reduce all forms of expression as much as possible to the single descriptive and narrative plane of the printed word. The advent of electric media released art from this straitjacket at once" (McLuhan 1964: 54). Bearing in mind the words of the Canadian philosopher, it can be assumed that liberature is a compromise between the traditional book, which limit forms of expression, and electronic media, which overcome the limitations.

Undoubtedly, liberature is inscribed in the milieu of contemporary art, which encourages reflection about the ways of perceiving the world, not from the position of an external, usually passive observer, but as an active

2 Pareyson writes: "there is no art that would not realize itself through adopting some physical matter, such as words (which are sounds, regardless of their meaning), colors, marble and stones, or the human body, as in mime and dancing" (Pareyson 2009: 54). 
participant, or even a co-creator of a work. This attitude means "a departure from the attitude of observation [...] to the attitude of immersion in the world [...] from noesis to aisthesis" (Wilkoszewska 1999: 21).

\section{Towards a new aisthesis}

It is precisely in the Greek word aisthesis that describes "perception through senses." Thus, in fact, the equivalent of aisthesis is, as Katya Mondoki remarks, the word "to perceive," and in this sense every experience remains, by definition, an aesthetic one (Mandoki 2007: 35). The author of Aesthetics beyond Aesthetics also emphasizes the fact that our refrence to reality and our cognition have an essentially aesthetic nature (Welsch 1997: 87). Whereas, following the argument by Rudiger Bubner, it is possible to say that aesthetic experience is simply a special case of ordinary human experience (Bubner 2005: 181). An analogous reflection is voiced by Berleant. The critic claims that although the phrase "sensory perception" remains by itself neutral, the fact that it is always additionally determined various, biological, historical, and cultural factors, and by our own personal experiences, which all gives our experience an aesthetic dimension. The aesthetic experience is, thus, not only culturally mediated, but is cultural by its nature (Berleant 2004: 45, 54). It remains in close relation with all human experiences, and encompasses not only art, but all other areas of reality, and requires by no means any particular attitude, distance, or detachment. Thus, the human sensory perception always has an aesthetic nature.

Aisthesis, meaning a broadly understood sensory perception, refers us both to distance receptors (vision and sound), and to contact receptors (touch, taste, smell). However, the category has been, in fact, always associated mostly with the senses of vision and sound, as the "higher ones." Physical perception, on the other hand, was given a lower status. The division into the sensual and the un-sensual was for a long time a consequence of the accepted duality of body and soul. As Arnold Berleant notices, the distinction, which is rooted in ancient Greece, was perhaps consequent of the fact that aisthesis was usually associated with the experience of fine arts (painting, sculpture, architecture, music, and poetry). In the traditional approach, thus, the discipline called "aesthetics" was concerned with arts, not with perception. This sprung from the conviction that artistic objects need a detached contemplation, and that the senses appropriate for contemplation are the distant receptors. The consequence was a peculiar denigration of contact receptors (Berleant 2004: 68-76). 
Today, however, the division between distant and contact receptors cannot be maintained, as it is claimed by Arnold Berleant, Wolfgang Welsch, or Richard Schusterman. The dualistic division of the human being into the carnal and the mental is defied by the very phenomenon of sensory perception, which is, after all, simultaneously psychic and somatic, as the author of Body Consciousness observes (Shusterman 2008: 186). The inventor of somaesthetics points out to the fact that the body is ever-present in human experience, even when we interact with advanced media technologies, and adds that "we cannot get away from the experienced body, its pleasures, pains and emotions" (Shusterman 1997: 47). Berleant, too, claims that "the sensual enters with the sensuous and, in a vast area of art and aesthetic experience; the sensual becomes a major if not predominant feature of its sensuous appeal. Indeed, the two are often indistinguishable" (Berleant 2004: 78). The division between distance and contact receptors becomes invalid, according to Berleant, also in confrontation with modern science and the knowledge that every sensory perception is simply a neurobiological activity (Berleant 2010: 57). Berleant also claims that "the aesthetic never loses touch with its origins in body activity and receptivity" (Berleant 2010: 44).

Moreover, in the context of contemporary art forms, the distinction between "mental" and "bodily" sense also seems invalid. The senses of vision and hearing, valued as "higher" ones, lose their privileged position in favor of an integrated complex of five senses. The five-sense human being experiences the world, as Katarzyna Otulakowska claims, "not only through vision/invision, but also through the touch, hearing, smell, and taste" (Otulakowska, 2010: 489). Wolfgang Welsch observes that "The field of aesthetic perception is polymorphous" (Welsch 1997: 96), and Berlant directly observes that definition of an art by the sense through which it was perceived leads to a distortion of aesthetic experience (Berleant 2004: 75). The author of Aesthetics beyond Aesthetics is close to this position, when he claims that overemphasis on one of the sense results in anesthesia or dormancy of the others. In this approach, the experience, apart from the aesthetic dimension, would also have an anesthetic one (Welsch 1998: 537). Thus, overemphasis on one sense at the expense of others cannot have good consequences for the human experience, as the experience would become impoverished and limited.

At present, thus, the somatic dimension of aesthetic experience, a dimension that was ignored by Kant, has been assuming more importance. The experience can no longer be reduced to disinterested liking or not liking that is to a mental state, an intellectual pleasure. Following Shuster- 
man, aisthesis can be defined as the use of the body as a medium of sensory-aesthetic consciousness (Shusterman 1997: 34). The aesthetic experience, as the philosopher claims, never exists solely in a human subject's head (Shusterman 2003: 306).

For the above mentioned critics (Berleant, Welsh, Shusterman), aisthesis has changed entirely the character it had before. It seems to be not only an aesthetic experience as such (which refers to art and all other fields of human activity), but the terms also, importantly, describes a mental and somatic dimension of every human perception. The terms rejects the divisions into "higher" and "lower" senses, treating all senses as equals, and referring simultaneously to psyche and soma. This is because, an aesthetic experience only reaches its synesthetic fullness when, as Berleant observes, all senses are activated to some degree (Berleant 2010: 86). Only in this framework, the multi-sensory and somatically experienced perception could overcome the understanding of aesthetic experience as a mental state of consciousness (Berleant 2010: 87).

This highly significant change in the understanding of the aisthesis was aptly described by Wolfgang Welsch, when he proposed the term reconfiguration of aisthesis. Welsch's phrase summarizes the polisensory, bodily and mental experience. The phrase also points out to the fact that the primary role of vision has been questioned in favor of other senses. The German critic claims that "The cards of sensibility are being reshuffled and instead of a firmly established hierarchy one tends either to an equitable assessment of all senses, or (which I would prefer) to different, purpose-specific hierarchies" (Welsch 1997: 87). Welsch identifies the roots of this change in the understanding of aisthesis, particularly in the dominance of media and development of new technologies. He also relates the change to constantly transforming patterns and demands of culture. In a broader perspective, however, the reconfiguration of aisthesis is not only the effect of various cultural changes (including the developments in media technology), but also of the transformations in art itself. New forms of art demand a new aisthesis, in which no sense will be able to dominate the others.

The above conviction is part of the category of "new aesthetic," proposed by Berleant. The category rejects the qualities of traditional aesthetics, and turns to, among other things, to new currents in art and to new artistic forms ${ }^{3}$, which, in turn, demands adequate work of perception. Listing

3 Among the many new forms of art, which demand new kinds of perceptive work, Berleant enumerates the happening, environment, film, functional architecture, and mobile sculpture (Berleant 2004: 85). 
the positive effects of the new aesthetic, the philosopher cites broadening of the art domain, as well as the perceptive integration of all elements of the aesthetic field ${ }^{4}$ : the creative, the objective, the appreciative, and the performative (Berleant 2004: 8). Berleant writes: "Not only have the distinctions between the creator of art, the aesthetic perceiver, the art object, and the performer have been obscured; their functions have tended to overlap and merge as well, becoming continuous in the course of aesthetic experience" (Berleant 2004: 67). He emphasizes the fact that expansion of the art domain results with appearance of such forms of art that provide a more dynamic experience for recipients, frequently demanding an inclusion of new sensory receptors, including the senses of touch and kinesthesis (Berleant 2004: 65-83). The demand for an increased activity by the audience also means that the boundary between the audience and the artist is blurred. Liberature, as it seems, is precisely one of these new forms of art, which embody the "new aesthetic," and consequently demand a new, reconfigured aisthesis.

\section{Liberature and the aesthetic experience}

Although Zenon Fajfer is right, when he writes "there is no book so all-ecompassing, no work so total that it would engage all the senses" (Fajfer 2010: $82 \mathrm{~A}$ ), liberature, as an object of aesthetic experience, demands a particular engagement by the reader. Being a peculiar combination of qualities typical for various arts (literature, visual arts, and even sculpture or architecture), it simultaneously transforms our mode of perception. This is because it demands simultaneous reception of the material, the iconic, and the verbal. As every work of art, it activates particular forms of perception, and by itself, to quote the author of Aesthetics beyond Aesthetics, it becomes a nexus where different forms of perception are combined. By referring to various senses, liberature activates numerous modes of perception and each time integrates them into a unique system (Welsch 1997: 91-96). This multiplicity and diversity of activated modes of perception of a work of liberature is inscribed in its very structure. This is because a work of liberature can assume practically any shape, appearance, and be made of practically any material, which is important for the sense of touch. When a conventional book form is modified, e.g. by closing a traditionally bound volume in covers made of concrete (as in Świątynia kamienia [The Temple

4 The idea of "aesthetic field" was already proposed by Berleant in 1970, in The Aesthetic Field. A Phenomenology of Aesthetic Experience. 
of Stone] by Andrzej Bednarczyk) or replaced by a glass bottle (as in Zenon Fajfer's Spoglądając przez ozonową dziurę [Looking through the Ozone Hole]), the traditional experience of reading must be entirely transformed.

Thus, it can be claimed that liberature, by promoting interactivity and necessity of multi-sensory perception, negates the traditional model of contemplation and the time-honored hierarchy of the senses, which mostly favored the vision. The vision, as Welsh observes, "is in fact no longer the reliable sense for contact with reality that it was once held to be - this no longer holds in a world in which physics has become indemonstrable, and just as little in the world of media" (Welsch 1997: 87). The vision is not privileged by modern forms of art either, including liberature.

In the case of works of liberature, thus, it is difficult to say that they refer to only one of the senses. Inasmuch as traditional painting is the art of vision, and traditional music is the art of hearing, liberature demands the activation of many receptors, including both "mental" and "somatic" ones. Quoting from Fajfer, it is possible to describe liberature as "a body for reading $[\ldots]$ with the eyes, ears, and hands; for seeing, hearing and touching". We begin to know a work of liberature as soon as we experience its weight, shape, or the texture of the paper (Fajfer 2010 A: 81).

Consequently, it demands simultaneous activation of both vision and touch. It can be even claimed that liberature activates the sense of kinesthesis, when a work demands physical manipulation of the volume, which is in fact a physical activity, an engagement of the body, to read a text written vertically or upside down, or to face a challenging shape or spatial dimensions of the work. Undoubtedly, thus, liberature demands polysensory reception. This is because, for an experience of a work of art, "only when complex does it succeed" (Welsch 1997: 96).

In the context of critical inquiry into the nature of liberature, the recipient remains the key category. As opposed to the reader of traditional literature, the recipient of liberature must be an unusually active discoverer of meanings, willing to face the challenges posed by liberature. As Agnieszka Przybyszewska observes, most works of liberature demand a recipient of the Dionysian type, whose activity helps to fulfill the meanings and complete the structure of the text (Przybyszewska 2005: 45). On the one hand, thus, the reader "creates" a works of liberature, when, in the act of perception, her or she determines its shape and rules of perception. Thus, the reader experiences the work in a different way each time, not only because of varying contexts of interaction with the artistic object (this aspect would be true for every aesthetic experience, regardless of whether it is of art or of an un-artistic object), but also since a work of liberature, because of its alinear quality and use of 
various specific materials, always demands new forms of reception. Quite often, for instance, liberature encourages endless changes in the sequence of reading/watching; it constantly forces the reader to make new choices.

On the other hand, as in Oka-leczenie, which remains a model example of the work of liberature, the freedom given to the reader is opposed by the demand for meticulous reading with the precision of "one-thusandth of a letter" (Fajfer 2010: 113 A). This does not change the fact that the reading of the three-volume work can be started from every volume, which is because Oka-leczenie combines three volumes into one. The three volumes correspond to three texts, referring to three different events, which, as Katarzyna Bazarnik writes, are connected on a hidden level, and mutually determined. The structure of Oka-leczenie, thus, points out to both the autonomy of each volume, and to the circularity of their narration (Bazarnik 2010: $155 \mathrm{~A}$ ). In fact, the three combined volumed forces the reader to "the circularity of tactile experience: opening of a book, in fact, has no ending, because when we close one part, we open up another one" (Kalaga 2010: 15). In other words, closing and opening, the beginning and end of the act of reading, assume a common identity. The book, thus, ceases to be a transparent medium, but becomes a structural element of the work. Everything is meaningful: the specific binding of the volume covers, the color of the grid and font, the shape and size of letters, their arrangement on the page, as well as the transformation of words into images.

All such elements are, for the reader, specific tasks to be performed. The experience of art, thus, becomes an act of creation, of an unceasing reconstruction of the order of experience. The performative act seems to be an indispensable factor in the experience of liberature. Following Pareyson, it is possible to say that performance seems to be the only possibility of access to the work (Pareyson 2009: 244).

Among the significant qualities of liberature, of particular importance are undoubtedly "interactivity and ergodicity, that is engagement of the reader into determination of the course of narration, and the reader's active participation in giving the work a final shape through the process of reading" (Bazarnik 2010: 160 A). Importantly, the ultimate shape is structured time and again, during each interaction with a work. The recipient's experience, in the words of Rüdiger Bubner, seems to be always new and inexhaustible. The aim of an aesthetic experience is the discovery of the unity of a work. This unity, in turn, remains the effect of reflection, oscillating between details and the whole work, in an attempt to capture mutual relations between them. Thus, the unity of a work is always unstable, and never allows us to capture the entirety of a work, which is unceasingly 
transformed in each act of perception. It is precisely in the unity of a work, as it was conceived of by Bubner, where the infinite repetitiveness of experience rests, so that the experience never wears out (Bubner 2005: 69, 74). It would be right to observe that each experience of a work gives it, as Luigi Pareyson wrote, "a new edition" (Pareyson 63).

To put it provokingly, the ultimate shape of a work in general, and a work of liberature in particular, is never ultimate. Contingency and alinearity as qualities of liberature create, as Tadeusz Miczka puts it, "a state of permanent aesthetic contingency" (Miczka 1999: 61). This is because a work is constituted "for a while" during reception. It exists, time and again, in performative gestures of sense-creation, which are forever changing in their versions. Materiality, verbality, and iconicity of a work of liberature always occur in new configurations during the process of experiencing. As Fajfer claims, sometimes the architectural aspect of a work can be dominating, at another time it can be the visual aspect, then the material one, or all of them combined (Fajfer 2010 A: 5) ${ }^{5}$ The whole remains elusive, however, The totality of a work cannot be captured, because, as Bubner puts it, the access to the totality is never full and ultimate. "In place of a logocentric model, there enters the principle of the aleatoric and spatial rhizome" (Kalaga 2010: 18). It is contingency and multiplicity that give the special quality to the experience of a recipient. Liberature would be a very suggestive example of it, because liberature demands particular enegagement, which Berleant describes as "aesthetic engagement."

This attitude, as the author of Sensibility and Sense presents it, radically refutes the Kantian proposition of dividing the aesthetic experience from the practice of life and from the sphere of cognition, and thus refutes the model of disinterested contemplation, which the critic calls "academic anachro-

${ }^{5}$ Fajfer writes that there are various types of liberature: the first kind is dominated by the architectural factor (so that the texts demand a particular structure of a book or its fragment), another kind is more visual (so that the graphical layer, e.g. photographs and drawings, is somehow integrated in the text or the text itself forms an image). Another type of liberature is represented by works whose material aspect is brought to the foreground (the paper and other materials constitute a sort of installation art) (cf. Fajfer 2010 A: 62).

6 Bubner argues that every interpretation is given with the work, and he describes this "freedom from the interpretation requirement" as the total aspect of art. In the notion of totality, thus, there is a conviction that everything that is necessary for the understanding of a work is already present in it. However, it is only in the meeting of totality with sensuality, in the process of aesthetic experiencing, that creates a specific tension between them. "It oscillates between sensual perception of austerity and lack of conceptual demand. [...] Witholding of this tension decides about the aesthetic experience in its entirety" (R. Bubner 2005, 73). 
nism" (Berleant 2004: 34). Engagement, in Berleant's terms, assumes a new meaning, which, as Krystyna Wilkoszewska observes, was eliminated from aesthetic and which should be associated with practical attitude (Wilkoszewska 2008: 219). This is because engagement demands an embodied subject to be introduced into aesthetic experience, a subject equipped with all senses, both contact and distance ones. It is precisely the category of embodiment ${ }^{7}$ that is employed to neutralize the traditional division into body and soul. This is because embodiment reaches its fullness through "active presence of the human body in appreciative experience" (Berleant 2004: 85), and demands inclusion, into an aesthetic activity, of not only of consciousness, but also of the bodily presence of the recipient. In this context, it is worthwhile recalling a pertinent observation by Teresa Pękala, who writes: "Interactive artistic activities, which demand cooperation of many senses, refer to cognitivity, especially to intellectual cognitivity. Its advantage is, undoubtedly, directness and striving for unity, resulting from the quality of emotions and polysensory quality of cognition" (Pękala 2008: 158). This kind of aesthetic interaction with a work is well described by the term engagement, which, being highly perceptive, demands more of somatic sensitivity, experiencing meanings rather than perceiving them intellectually (Berleant 2004: 84). It is possible to say, quoting from Maurice Merleau-Ponty, that the body knows more, because it records all previous perceptions and experiences, even the unconscious ones (Merleau-Ponty 2002: 231).

Berleant argues that engagement corresponds "far better than disinterestedness the perceptual, cognitive, and somatic involvement that responsive appreciation joins to powerful art" (Berleant 2004: 9). Intimate participation would be an indispensable quality of engagement, since it allows us to "overcome the sense of separateness that divides us from things"

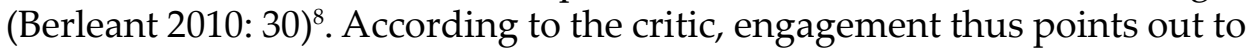
two very important qualities of aesthetic experience: its active character, and participation as its indispensable quality (Berleant 2004: 35).

Precisely this kind of activeness and participation is demanded by works of liberature. Interaction with liberature is certainly of a different quality than

7 Berleant writes about embodiment in two fundamental meanings. In the first meaning, the "aura of physical presence is embedded in the art work," whereas in the second it "occurs in the aesthetic response to art when the somatic participation of the appreciator is involved" (Berleant 2004: 84).

8 Importantly, the category of aesthetic engagement is also used by Berleant for emphasizing the continuity of art. It is a specific bridge between traditional art and its modern forms (Berleant 2004: 18)

Aesthetic engagement was already discussed by Berleant in his pioneering work, Art and Engagement, Temple University Press, Philadelphia 1991. 
in the case of traditional books, but undoubtedly in liberature, too, the touch of the book, as well as "the look, feel and smell of its pages present a special axis of experience" (Shusterman 1997: 45). In a work of liberature, the recipient faces the challenge of synthesizing, in the experience of reception, the material, verbal, and iconic dimensions of a work. Remembering about the attitude of engagement, it must be emphasized that in works of liberature, unlike in traditional books, even the script itself can be challenging for the recipient. This is because in liberature the script is not only a "prosthetic" for the spoken language. It does not merely constitute a physical foundation for the spoken language, as Roman Ingarden would put it (Ingarden 1973: xxvxxvii), but is simultaneously a text and an image, and by expressing meanings, the script also, as it were, embodies them. This is because liberature has turned the qualities of the printed script into one of its most important subject-matters, and for this reason liberature does not allow "to make for a transient perception of print or handwriting, and to facilitate the progress towards perception of a typical sound of a word and of its meaning" (Ingarden 1981: 278). On the contrary, it is possible to say that in a work of liberature, as in, for instance, in concrete poetry, the script "plays" with its own graphics, or, to put it in a different way, that we interact with the sceno-graphics of script. The play with script can be, of course, dismissed as a peculiar form of barrier to "access" to the meanings hidden in the text, but it can also be seen as a challenge for a patient and inquisitive reader.

The emanative text is certainly a special case of liberature ${ }^{9}$. The creator of emanative text admits that this peculiar novelistic experiment was conceived of as an expression of perfect iconicity. By remaining invisible, it still can be seen (Fajfer 2010: 97 A). It demands an increased activity and a specific kind of perception in order to realize itself. It must be emphasized that in an emanative text there is inscribed a necessity for an

9 The emanative text, at least to a degree, can be treated as a peculiar reference to the anagrammatic concept of literature, as proposed by Ferdinand de Saussure. This is because anagrams, as well as emanative texts, create "secondary meanings and secondary texts, which are [...] hidden, but which are at the same time obvious" (Dziadek 2006: 50). Both projects, referring to the book by Jean Starobinski, Les mots sous les mots. Les anagrammes de Ferdinand de Saussure, Paris, Gallimard, 1971, can be described as "words under words." It must be emphasized, however, that inasmuch as the script and single letters as being important for an "embodiment" of an emanative text, de Saussure's anagrams were primarily phonetic. Their meaning, thus, diverges from the traditional literary and theoretical approach. In the analyses of the Swiss linguist, the primary goal was to read and record various combinations of sounds, not letters (cf. Dziadek, 2006: 34). Importantly, in an emanative text all layers of text are given to the reader, even if not directly, whereas the method of anagrammatic reading never gives certainty that the word found is the only one, that there are no other theme-words (cf. Dziadek, 2006: 38-39). 
unusually strong engagement by the reader, who literally brings the text into existence. This is because the reader cannot, as in the reading of a traditional script, give the text a cursory glance, because the text becomes visible through attentive effort. By following the instructions given by the author, the participatory reader must remove several layers of the text to discover the camouflaged meanings and to give an incarnation to, as Zenon Fajfer put it, "the incorporeality of a higher order" (Fajfer 2010: 113 A).

The idea of an emanative text involves the need to read the initial letters of each word, as a new layer text surfaces from under the initials, and then another and another, until the journey's end, where the reader finds the source-word ${ }^{10}$ (Fajfer $2010 \mathrm{~A}: 126 \mathrm{~B}$ ). On the one hand, it is possible to ascribe a particular importance, or consistence, to this expression, because all the previously eliminated layers of meaning are summarized. On the other hand, it seems to be important that the discovery of the source-word simultaneously forces the reader to remove, or in fact negate, all the "bypassed" layers of text. Emanative text, thus, is not played out between what is visible and invisible, but also between presence and destruction, between words, but also without them. Its essence can be aptly described in John Dewey's words: "The visible is set in the invisible; and in the end what is unseen decides what happens in the seen; the tangible rests precariously upon the untouched and ungrasped" (Dewey 1958: 43-44).

The recipient, by reconstructing the invisible, and discovering several layers of meaning, becomes, as Agnieszka Przybyszewska observes, a guarantor of coherence of a work (Przybyszewska 2005: 57). Thus, a work of liberature, and particularly an emanative text, exists thanks to the interactive work of a perceiver. The necessity for active interaction, which, as Anna Łebkowska observes, is similar to reading an interactive hypertext novel (Łebkowska 2008), is simply inscribed in the text. It would not be an exaggeration to say that, in a sense, liberature is similar to multimedia art, with its characteristics, as Maria Popczyk argues, interactivity, creation of a work during reception, and unpredictable versions of the final results (Popczyk 1999: 133-134). To quote from McLuhan's terminology, it is possible to define liberature as a cold medium, which, as opposed to hot media, forces the reader to cooperate and fill in (McLuhan 1964: $201 \mathrm{ff}$ ).

The engagement of the recipient in the experience of liberature has, thus, an unquestionable sensual and conscious dimension. It poses challenges

10 "Source-word" can be associated with the "theme-word," which was an important element of the anagrammatic concept of reading by de Saussure. The linguist even claimed that the writing of texts based on anagrams was, in fact, a decomposition of the themeword by a creative writer (cf. Dziadek 2006: 38). 
and intensifies the spaces of interpretation, it forces the recipient to be inquisitive, to decipher meanings, and even to set up the structure of a text. The effort of facing all these requirements can be, of course, a source of aesthetic satisfaction, but at the same time, it must be admitted that an excess of stimuli can cause a dispersal and erasure of meanings, or even discourage the recipient. "Whoever is constantly exposed to optical and acoustic provocations, eventually ceases to see and hear" (Bubner 2005: 182). Similarly, Richard Schusterman observes that the media that engage in most sensory modalities can actually impoverish our experience (Shusterman 1997: 45).

In the case of liberature, too, the iconic layer of work and the material dimension of a work, can be, as it seems, a diversion and an addition to the verbal layer, but might just as well be received as an obstacle on the way to the meanings of a text. This is because it is difficult to discard the traditional habits of linear reading. Independence given to the recipient, which can be seen as an invitation for the co-creation of a work, which often leads to uncertainty and helplessness. Wojciech Kalaga is right, when he writes that the two ontological orders combined in liberature, the intentional and the material-visual, can cooperate to provide a different experience of reading, but they can also do the reverse, and lead to a dispersal of meanings in the recipient's experience (Kalaga 2010: 19).

The deliberations presented above lead to the conclusion that liberature as a "total art" in which "the matter of the statement belongs to the space of the book, and the space of the book to the material of the statement" (Fajfer 2010: 125 A), demands also a total aisthesis. Paradoxically, however, the totality can turn out to be a trap set against the recipient who desires more sensations. This is because, on the one hand, liberature can certainly be a pleasing surprise and question our received habits of perception, bringing freshness and novelty. On the other hand, however, liberature can be simply irritating and confusing. As it seems, the necessity of giving the same importance to all senses, which liberature demands, can actually eliminate the effect of increasing the aesthetic satisfaction, instead of bringing it about. Thus, ironically, the excess of sensations, which activate various sensory receptors, can lead us to disappointment, instead of an aesthetic fulfillment; it can lead from aesthesis to anaisthesis (Welsch: 1998 $)^{11}$. As it seems, one must be "careful with liberature!"12

${ }^{11}$ Cf. also Odo Marquard's Aesthetica i anaesthetica. Rozważania filozoficzne, transl. K. Krzemieniowa, Warszawa 2007.

12 The expression "Careful with liberature" is a paraphrase of the title of the book Ostrożnie z literaturą! (przykłady, wykłady raz inne rady), [Careful with literature! (Translations, lectures and other pieces of advice)], ed. S. Balbus, W. Bolecki, Warszawa 2000. 


\section{Bibliography}

Bazarnik Katarzyna 2010a, Liberature or on the Origin of Literary Species, [in:] Zenon Fajfer, Liberatura czyli literatura totalna. Teksty zebrane z lat 1999-2009 / Liberature Or Total Literature. Collected Essays 1999-2009, trans. and ed. K. Bazarnik, Cracow: Korporacja Ha!art.

Bazarnik Katarzyna 2010b, Materialność jako wyznacznik gatunkowy liberatury [in:] Materia sztuki ed. M. Ostrowicki, Cracow: Universitas.

Berleant Arnold 2004, Re-thinking aesthetics: Rogue Essays on Aesthetics and the Arts, Aldershot: Ashgate Publishing.

Berleant Arnold 2010, Sensibility and Sense: The Aesthetic Transformation of the Human World, Exeter, Imprint Academic.

Bubner Rüdiger (2005), Doświadczenie estetyczne, Warszawa, Oficyna Naukowa.

Dewey John (1958), Experience and Nature, wyd. 2, Dover Publications, New York.

Dziadek Adam (2006), Na marginesach lektury. Szkice teoretyczne, Katowice: Wydawnictwo Uniwersytetu Śląskiego.

Dziamski Grzegorz 2007, Wizje i re-wizje. Wielka księga estetyki w Polsce, ed. K. Wilkoszewska, Cracow: Universitas.

Fajfer Zenon 2010a, Liberatura czyli literatura totalna. Teksty zebrane z lat 1999-2009, red. K. Bazarnik, Cracow: Korporacja Ha!art.

Fajfer Zenon 2010b, Od liberatury do tekstu niewidzialnego (autoportret $z$ Ingardenem $w$ tle), [in:] Materia sztuki, ed. M. Ostrowicki, Cracow: Universitas.

Goban-Klas Tomasz 2011, Wartki nurt mediów. Ku nowym formom społecznego życia informacji. Pisma z lat 2000-2011, Cracow: Universitas.

Ingarden Roman 1973, The Literary Work of Art. Evanston, Evanstone, IL: Northwestern University Press.

Ingarden Roman 1981, Wykłady i dyskusje z estetyki, ed. A. Szczepańska, introduction W. Stróżewski, Warsaw: PWN.

Kalaga Wojciech 2010, Liberature: Word, Icon, Space. Introduction, [in:] Zenon Fajfer, Liberatura czyli literatura totalna. Teksty zebrane z lat 1999-2009 / Liberature Or Total Literature. Collected Essays 1999-2009, trans. and ed. Katarzyna Bazarnik, Cracow: Korporacja Ha!art.

Kant Immanuel 1986, Krytyka władzy sądzenia, trans. J. Gałecki, Warsaw: PIW.

Łebkowska Anna 2008, Doświadczenie interakcji i identyfikacji (Hipertekstowa powieść interaktywna), [in:] Nowoczesność jako doświadczenie. Analizy kulturoznawcze, ed. A. Zeidler-Janiszewska, R. Nycz, B. Giza, Warsaw: Wydawnictwo SWPS Academica.

Mandoki Katya 2007, Everyday Aesthetics: Prosaics, the Play of Culture and Social Identities, Aldershott: Ashgate.

Marquard Odo 2007, Aesthetica i anaesthetica. Rozważania filozoficzne, trans. K. Krzemieniowa, Warsaw: Oficyna Naukowa.

Merleau-Ponty Maurice 2002, Phenomenology of Perception, trans. C. Smith. London: Routlege Classics. 
McLuhan Herbert Marshall 1964, Understanding Media, New York: McGraw-Hill.

Miczka Tadeusz 1999, Multimedia - oczywistości i domysty. Szkic o estetycznej przygodności nowych mediów, [in:] Piękno w sieci. Estetyka i nowe media, ed. K. Wilkoszewska, Cracow: Universitas.

Otulakowska Katarzyna 2010, Zero jedynkowa zmysłowość człowieka, [in:] Materia sztuki, ed. M. Ostrowicki, Cracow: Universitas.

Pareyson Luigi 2009, Estetyka. Teoria formatywności, trans. K. Kasia, Cracow: Universitas.

Pękala Teresa 2008, Estetyczne doświadczenie przeszłości, [in:] Nowoczesność jako doświadczenie. Dyscypliny, paradygmaty, dyskursy, eds. A. Zeidler-Janiszewska, R. Nycz, Warsaw: Wydawnictwo SWPS Academica,.

Popczyk Maria 1999, Dzieło sztuki jako medium, [in:] Piękno w sieci. Estetyka i nowe media, ed. K. Wilkoszewska, Cracow: Universitas.

Przybyszewska Agnieszka 2005, Niszczyć, aby budować. O nowych jakościach liberatury $i$ hipertekstu, [in:] Tekst-tura. Wokót nowych form tekstu literackiego i tekstu jako dzieła sztuki, ed. M. Dawidek Gryglicka, Cracow: Korporacja Ha!art. 